\title{
Disinfection and removal of human pathogenic bacteria in arctic waste stabilization ponds
}

Huang, Yannan; Hansen, Lisbeth Truelstrup; Ragush, Colin M. ; Jamieson, Rob C.

\section{Published in:}

Environmental Science and Pollution Research

Link to article, DOI:

10.1007/s11356-017-8816-9

Publication date:

2018

Document Version

Peer reviewed version

Link back to DTU Orbit

Citation (APA):

Huang, Y., Hansen, L. T., Ragush, C. M., \& Jamieson, R. C. (2018). Disinfection and removal of human pathogenic bacteria in arctic waste stabilization ponds. Environmental Science and Pollution Research, 25(33), 32881-32893. https://doi.org/10.1007/s11356-017-8816-9

\section{General rights}

Copyright and moral rights for the publications made accessible in the public portal are retained by the authors and/or other copyright owners and it is a condition of accessing publications that users recognise and abide by the legal requirements associated with these rights.

- Users may download and print one copy of any publication from the public portal for the purpose of private study or research.

- You may not further distribute the material or use it for any profit-making activity or commercial gain

- You may freely distribute the URL identifying the publication in the public portal 

stabilization ponds

3

4

5

6

7

Yannan Huang, Lisbeth Truelstrup Hansen ${ }^{1 *}$, Colin M. Ragush, Rob C. Jamieson,

8

9 Centre for Water Resources Studies, Dalhousie University, Halifax, Nova Scotia, Canada B3H

$10 \quad 4 \mathrm{R} 2$

11

12 Present address:

13 1. National Food Institute, Technical University of Denmark, Kgs. Lyngby, Denmark

14

15

16

17

18 * Corresponding author: Lisbeth Truelstrup Hansen (litr@food.dtu.dk)

19

20 


\section{ABSTRACT}

22 Wastewater stabilization ponds (WSPs) are commonly used to treat municipal wastewater in

23 Arctic Canada. The biological treatment in the WSPs is strongly influenced by climatic

24 conditions. Currently, there is limited information about the removal of fecal and pathogenic

25 bacteria during the short cool summer treatment season. With relevance to public health, the

26 objectives of this paper were to determine if treatment in arctic WSPs resulted in the disinfection

27 (i.e., removal of fecal indicator bacteria, Escherichia coli) and removal of selected human

28 bacterial pathogens from the treated effluent. The treatment performance, with focus on

29 microbial removal, was assessed for the one-cell WSP in Pond Inlet (NU) and two-cell WSP in

30 Clyde River (NU) over three consecutive (2012-2014) summer treatment seasons (late June-early

31 September).

32 The WSPs provided a primary disinfection treatment of the wastewater with a 2-3 log

33 removal of generic indicator E. coli. The bacterial pathogens Salmonella spp., pathogenic E. coli,

34 Listeria monocytogenes, but not Campylobacter spp. and Helicobacter pylori, were detected in

35 the untreated and treated wastewater, indicating human pathogens were not reliably removed.

36 Seasonal and annual variations in temperature significantly $(\mathrm{p}<0.05)$ affected the disinfection

37 efficiency. Improved disinfection and pathogen removal was observed for the two-cell system in

38 Clyde River as compared to the one-cell system in Pond Inlet. A quantitative microbial risk

39 assessment should be performed to determine if the release of low levels of human pathogens

40 into the arctic environment poses a human health risk.

41

42 Keywords: Wastewater treatment, Arctic Canada, municipal wastewater, disinfection, fecal

43 indicator bacteria, bacterial pathogens, wastewater temperature 


\section{INTRODUCTION}

45 In Canada's Arctic regions (Nunavut, Nunavik and Northwest Territories), wastewater

46 stabilization ponds (WSPs) continue to be the most common wastewater treatment solution to

47 manage municipal wastewater. Since there is no need to add chemical flocculants and install

48 mechanical equipment to aerate and mix the wastewater, the WSPs can be easily operated and

49 maintained despite a limited capital and operational budget. However, WSPs, which are

50 completely reliant on un-aided natural biological processes to treat wastewater, may experience

51 treatment limitations due to the harsh arctic climate and not be able to achieve treatment goals set

52 out by Canada-wide strategy for the management of municipal wastewater in the new

53 Wastewater System Effluent Regulation (Environment Canada 2015).

54 In the majority of Nunavut's 25 small and remote communities, WSPs operate as retention

55 lagoons with no discharge during the winter period. During the nine months of winter the

56 perimeter of the ponds (surface, walls and floor) are frozen while the interior liquid hovers

57 around the freezing point. In June the ponds begin to thaw, and the entire volume remains liquid

58 until freeze-up starts in September. This period of 2-3 months is called the "treatment season”, as

59 it characteristically has higher biological activity (phytoplankton and bacteria) due to warmer air

60 temperatures and extended daylight yielding elevated water temperatures. In September before

61 the freeze-up, the contents of the ponds are discharged either directly into the aquatic receiving

62 environment or to a natural tundra wetland for further polishing.

63 Release of inadequately treated wastewater with a content of human infectious pathogens

64 into the environment may pose a potential human health risk. People living in Nunavut

65 communities may particularly be at risk as their diets are reliant on the local harvest of food from

66 traditional sources (Daley et al. 2014). In addition, recreational activities often take place near 
67 wastewater effluent discharging areas (Harper et al. 2011, Daley et al. 2017). Finally, the

68 overcrowded housing in these communities may be exacerbating the frequency of inter-person

69 spread of infectious agents (Goldfarb et al. 2013, Harper et al. 2011). From a public health

70 perspective, it is important to investigate whether current WSPs in Nunavut achieves compliance

71 with disinfection goals and removal of human bacterial pathogens to minimize the pathways for

72 the transmission of infectious diseases.

73 Many bacterial pathogens have been associated with waterborne diseases, including the

74 enteric pathogenic Escherichia coli serotypes such as O157:H7, Salmonella spp., Campylobacter

75 spp., Helicobacter pylori and the non-enteric, environmental Listeria monocytogenes. Outbreaks

76 of enterohemorrhagic E. coli (EHEC) O157:H7 have occurred in Canada's northern communities.

77 While the original source of infection was not identified, person-to-person transmission was in

78 both cases suggested as a significant risk factor (Rowe et al. 1994, Orr et al. 1994). Goldfarb et al.

79 (2013) tested 86 stool specimens, which had been obtained from patients with diarrhea at the

80 hospital in Iqaluit (NU), for the presence of 50 different bacterial, viral and parasitic pathogens.

81 They detected Salmonella spp. and Campylobacter spp. in 47\% of the specimens, indicating that

82 outbreaks of Salmonella spp. and Campylobacter spp. may have occurred. H. pylori infections

83 have arisen as an emerging health concern in communities in the Canadian Arctic with the

84 detection of the bacterium in community water supplies in Chesterfield Inlet (NU) and Repulse

85 Bay (Naujaat, NU) (Lefebvre et al. 2013, Goodman et al. 2008, McKeown et al. 1999). The cold-

86 tolerant L. monocytogenes is mainly associated with foodborne outbreaks such as the large

87 outbreak in 2008 in Ontario, Canada (Weatherill et al. 2009). This environmental bacterium can

88 be readily isolated from fresh water in Southern Canada (Stea et al. 2015, Lyautey et al. 2007)

89 while its presence in the arctic environment is unknown. 
At the present time, there is a lack of information regarding the removal of fecal indicator

91 bacteria (i.e., disinfection) and human bacterial pathogens in WSPs in Nunavut. To close this

92 knowledge gap, the objectives of the present study were to determine if treatment of municipal

93 wastewater in arctic WSPs successfully removes fecal indicator bacteria (E. coli) and selected

94 human bacterial pathogens (pathogenic E. coli serotypes (e.g., O157:H7), Salmonella spp.,

95 Campylobacter spp., and H. pylori, and the non-enteric L. monocytogenes). The treatment

96 efficacy was investigated over three years (2012-2014) in the two remote communities in

97 Nunavut, Pond Inlet and Clyde River, which are serviced by WSP treatment systems consisting

98 of a single cell and two cells, respectively.

99

100 MATERIALS AND METHODS

101

\section{Study sites}

103 From September, 2012 to September, 2014, seven sampling trips were made to Pond Inlet

104 (latitude $72^{\circ} 41^{\prime} 57^{\prime \prime} \mathrm{N}$, longitude 77 57' 33" W; population: 1549 [Statistics Canada 2012]) and 105 another six sampling trips to Clyde River (latitude $70^{\circ} 28^{\prime} 26^{\prime \prime} \mathrm{N}$, longitude $68^{\circ} 35^{\prime} 10^{\prime \prime} \mathrm{W}$;

106 population: 934 [Statistics Canada 2012]). Both Pond Inlet and Clyde River are remote fly-in

107 communities that are located on the eastern shore of Baffin Island, in Nunavut's Qikiqtani region.

108 Both communities have polar arctic climates with long cold winter and short cool summers.

109 Based on 1981 to 2010 Canadian climate normals, February is the coldest month with daily

110 average temperatures of $-34^{\circ} \mathrm{C}$ in Pond Inlet and $-30{ }^{\circ} \mathrm{C}$ in Clyde River, while July is the

111 warmest month with daily average temperatures of $6{ }^{\circ} \mathrm{C}$ in Pond Inlet and $5^{\circ} \mathrm{C}$ in Clyde River 
112 (Environment Canada 2014). Most of people living in these communities are Inuit, who follow a 113 traditional lifestyle of hunting and fishing.

114 Pond Inlet employs a one-cell engineered WSP, which was commissioned in 2005 and is

115 located approximately $1.4 \mathrm{~km}$ to the east of the hamlet. All wastewater generated is delivered by 116 trucks to the WSP. The treated wastewater is discharged from the WSP once annually, usually 117 over a three week period starting in September and ending in early October just prior to freeze118 up. The wastewater effluent exits the WSP over the berm and travels through a ditch and then 119 down a steep hill (500 m) before arriving in the ocean receiving environment (Eclipse Sound).

120 The WSP was designed to be a facultative pond with a surface area of approximately 4 ha and an 121 average depth of approximately $1.9 \mathrm{~m}$ during the summer. The estimated volume of wastewater 122 effluent discharged is $8.0 \times 10^{7} \mathrm{~L}$. Traditional uses of the ocean receiving environment include 123 fishing and hunting. During the summer season, especially in July and August, schools of Arctic 124 char migrate past the wastewater effluent discharge point. The timing of the annual decant is 125 therefore timed to coincide with the departure of the Arctic char from the area. In addition, 126 during the August and September sampling trips, hunting of narwhals and seals in the nearshore 127 environment surrounding the community was observed.

128 Clyde River recently expanded their WSP system to include a larger, secondary pond in 129 2011. The original WSP, the primary pond, had due to the increasing population become too 130 small to accommodate the annual wastewater volume. Therefore, the secondary pond was built 131 to increase the wastewater holding capacity. The expected annual wastewater volume is $3.1 \times 10^{7}$

132 L using the assumption that each of the 934 inhabitants produces $90 \mathrm{~L}$ of wastewater per day.

133 The intended use of the two-cell WSP system is a scheme where the raw wastewater is dumped 134 into the primary pond to enable settling and precipitation processes. At regular intervals, pre- 
135 processed wastewater should then be transferred from the primary pond into the secondary pond

136 to receive further treatment before the annual decant from the secondary pond, where treated

137 wastewater is passed through a vegetated filter strip before going into the ocean receiving

138 environment (Patricia Bay).

\section{Sampling strategy}

141 The same sampling strategy was used in Pond Inlet and Clyde River during visits from

142 September 2012 to September 2014, where representative samples were obtained of raw

143 wastewater from trucks, wastewater in different parts and depths of the WSPs and treated

144 wastewater just prior to the decant (Clyde River) or during the decant (Pond Inlet). In Pond Inlet,

145 outfall samples, i.e., the effluent just prior to entry into the ocean receiving environment, were

146 also collected. In addition, the ocean samples from the immediate vicinity of the outfall point,

147 were collected before and during the decant event in Pond Inlet. Specifically, four outfall

148 samples were collected in both 2013 (two samples) and 2014 (two samples) during the decant

149 event. Six ocean samples from the immediate vicinity of the outfall point, were also collected

150 before (three samples) and during the decant event (three samples) in Pond Inlet in September

1512014.

152 The first trip to Pond Inlet and Clyde River was the end of the summer treatment season in

153 2012. The WSP in Pond Inlet was sampled at the start, middle, and end of the summer treatment

154 season, including decant events, in 2013 and 2014. Both the primary and secondary ponds in

155 Clyde River were sampled at the start, middle, and end of the summer treatment season in 2013,

156 while in 2014 the ponds were sampled at the start and end of the summer just prior to the decant

157 event. The sampling events representative of the start, middle, and end of the summer treatment 
158 season took place late June/early July, late July/early August, and early/middle September,

159 respectively.

161 Continuous WSPs monitoring parameters collection

162 Deployment of multi-parameter sondes (YSI Inc., Yellow Spring, OH) allowed for in-situ

163 measurements of wastewater temperature, $\mathrm{pH}$, and dissolved oxygen (DO). During the first

164 sampling trip in each year, the sondes were installed in the WSPs to record the parameters hourly

165 until the sondes were retrieved at the end of the treatment season. In addition, HOBO

166 temperature/light pendants, temperature/water level loggers and ROX DO probes (Onset

167 Computer Corporation, Cape Cod, MA) were installed at various depths of the WSPs to capture

168 parameters and also to validate the continuous recording measured by the in-situ sondes.

169

\section{Degree days calculation}

171 'Degree days' is a concept used in the agricultural field to indicate the accumulative effect

172 of temperature on the growth potential of plants in a specific geographical site. Use of degree

173 days also allows for comparison of biological activity in wastewater treatment carried out in

174 different geographical sites with different climates (Ragush et al. 2015). To calculate degree days

175 in order to study how temperature influenced the disinfection performance of WSPs in Pond Inlet

176 and Clyde River, the surface wastewater temperatures were used. The calculation of degree days

177 involves averaging temperature measurements for each day and then subtracting the reference

178 temperature. In this study, the reference temperature was chosen as $5^{\circ} \mathrm{C}$. For example, if the

179 average temperature at a specified day 1 was $10^{\circ} \mathrm{C}$ then this would lead to a degree day value for

180 that day of $5\left(10^{\circ} \mathrm{C}-5^{\circ} \mathrm{C}=5^{\circ} \mathrm{C}\right)$. In this calculation, only days with average temperature above 
$1815{ }^{\circ} \mathrm{C}$ are considered, meaning that on days where, for example, the average temperature is $2{ }^{\circ} \mathrm{C}$,

182 the degree day value would be recorded as 0 . To obtain the total degree day values for a certain

183 number of days, the number of degrees for each day is summed up for the specified period, i.e.,

184 the degree days for a period of three days would be $6(5+1+0)$ if the degree days were recorded 185 as follows on day $1=\left(10-5^{\circ} \mathrm{C}\right)=5$, day $2=\left(6-5^{\circ} \mathrm{C}\right)=1$, day $3=\left(2-5^{\circ} \mathrm{C}\right)=0$.

\section{Microbiological sample analysis}

Wastewater samples were obtained in sterile $1 \mathrm{~L}$ or $500 \mathrm{~mL}$ containers (Nalgene, Fisher

189 Scientific, Nepean, ON, Canada), stored in a cooler $\left(4{ }^{\circ} \mathrm{C}\right)$ and flown to the Northern Water

190 Quality Laboratory (NWQL) at the Nunavut Research Institute in Iqaluit, NU. Upon arrival to

191 NWQL, the analysis for the content of fecal indicator bacteria (E. coli) was performed

192 immediately. Samples were also flown to Halifax, NS for the commencement of the selective

193 enrichment for pathogenic bacteria within 24 to 48 hours. DNA was also extracted from

194 wastewater samples within 24 hours of the original sampling event. The immediate processing

195 was done to minimize changes in the microbiology of the samples due to the transportation time.

197 Enumeration of fecal indicator bacteria (E. coli)

198 Fecal indicator bacteria (E. coli) were enumerated using the American Public Health

199 Association (APHA) Standard Method 9223 (American Public Health Association 1998).

200 Samples were processed using Colilert ${ }^{\circledR}-18$ and Quanti-Trays $/ 2000^{\circledR}$ following the

201 manufacturer's procedure (IDEXX Laboratories, Inc., Westbrook, ME, USA). The result was log

202 transformed and expressed as Log MPN/100 mL. 


\section{Kinetics of $\boldsymbol{E}$. coli removal}

205 First order rate constants were calculated to estimate $E$. coli removal rates based on the

206 assumption of a completely mixed batch reactor, an assumption which was supported by water

207 quality results from both Pond Inlet and Clyde River WSPs. This first order rate constant was a

208 conservative estimate of $E$. coli removal rates because of the limited sample size. The impact of

209 not including the continuous addition of raw wastewater was expected to be small, because the

210 additional wastewater being added during the treatment period (ranging from 31-34 days in Pond

211 Inlet (start to middle of the treatment season) and 64-74 days in Clyde River (start to end)) only

212 represented $1 / 12^{\text {th }}$ of the annual wastewater volume in Pond Inlet, and $1 / 6^{\text {th }}$ of the annual

213 wastewater volume in Clyde River. Therefore, the actual rate constant would be expected to be

214 higher than the conservative rate constant.

215 The first order rate constant for E. coli removal was calculated as follows:

$$
\mathrm{K}=-\operatorname{Ln}\left(\mathrm{C}_{\mathrm{t}} / \mathrm{C}_{0}\right) / \mathrm{t}
$$

217 Where:

$218 \mathrm{~K}$ is the first order rate constant (1/day)

$219 \mathrm{C}_{0}$ is E. coli concentration (Log MPN/100 mL) at the beginning season in the WSP

$220 \mathrm{C}_{\mathrm{t}}$ is E. coli concentration (Log MPN/100 mL) at the middle season for Pond Inlet and at the end

221 season for Clyde River WSPs

222 t is the time interval between the two treatment seasons (days)

224 Detection of bacterial pathogens presence/absence and concentrations by TaqMan

225 quantitative polymerase chain reaction (qPCR) assays. 
Duplicate wastewater samples (10 mL each) were subjected to an initial pathogen enrichment

227 step in Fraser, Bolton, Rappaport-Vassiliadis, buffered peptone water for L. monocytogenes,

228 Campylobacter, Salmonella and pathogenic Escherichia coli serotypes, respectively. The

229 enrichment steps were carried out using previously published protocols (Stea et al. 2015a and

230 2015b). Following enrichments, $2 \mathrm{~mL}$ from each of the enrichment broths were combined and

231 added into a $15 \mathrm{~mL}$ sterile test tube and were centrifuged at $3200 \mathrm{x} \mathrm{g}$ for 10 minutes to obtain

232 cell pellets for DNA extractions. DNA was extracted from cell pellets using the PowerSoil

233 MoBio kit (MoBio, Carlsbad, CA, USA) following the manufacturer's instructions with a final

234 volume of $100 \mu \mathrm{L}$. Each qPCR reaction (25 $\mu \mathrm{L})$ consisted of $7.7 \mu \mathrm{L}$ of DNase-free water (Fisher

235 Scientific), $12.5 \mu \mathrm{L}$ of TaqMan master mix (Applied Biosystems Fast Advanced 2X, Applied

236 Biosystems), $0.3 \mu \mathrm{L}$ each of $10 \mu \mathrm{M}$ forward and reverse primers, $0.2 \mu \mathrm{L}$ of $10 \mu \mathrm{M}$ TaqMan

237 hydrolysis probes, and $4 \mu \mathrm{L}$ of sample DNA. The qPCR primers, TaqMan hydrolysis probes,

238 running conditions for Campylobacter spp., Salmonella spp., pathogenic E. coli and L.

239 monocytogenes were described in Lund et al. (2004), Cheng et al. (2008), Ibekwe et al. (2002),

240 Rodriguez- Lazaro et al. (2004) and Stea et al. (2015b), respectively, and also listed in the

241 supplemental material (Table S1) together with details of the qPCR conditions. Bioinformatic

242 analysis revealed that the Ibekwe et al. (2002) method, which targets the eae gene (intimin),

243 detected enterohemorrhagic and enteropathogenic E. coli (e.g., O157:H7, O145:H28, O55:H7

244 and O111:H7, see the full list and eae amplicon alignment in the supplemental material, Figure

245 S1). Positive controls contained DNA that were extracted from Salmonella Typhimurium (ATCC

246 14028, Manassas, VA, USA), E. coli O157:H7 (strain EC 961019, kindly provided by H. Schraft,

247 Lakehead University, Thunder Bay, ON, Canada), Campylobacter jejuni, C. lari, and C. coli

248 strains (kindly provided by L. Waddington, Canada Food Inspection Agency, Dartmouth, NS, 
249 Canada), and L. monocytogenes 568 (serogroup IIa). Negative controls consisted of DNA

250 extracted from sterilized enrichment media. Each qPCR run contained positive, negative, and

251 non-template controls, and samples. The qPCR detection was performed in a StepOne Plus

252 system (Applied Biosystems). The results were reported as the presence/absence of each

253 pathogen in $10 \mathrm{~mL}$ of wastewater originally used in the pathogen enrichment protocols.

254 To quantify pathogen cell numbers in each sample, $100 \mathrm{~mL}$ wastewater volumes were

255 centrifuged at $3200 \mathrm{x}$ g for 10 minutes to harvest microbial cells. DNA was extracted from the

256 cell pellets using the PowerMax Soil DNA isolation MoBio kit (MoBio, Carlsbad, CA, USA)

257 following the manufacturer's instructions. The final volume for each DNA extract was $100 \mu \mathrm{L}$.

258 In addition to detection of the pathogens mentioned above, the presence/absence of $H$. pylori was

259 also analyzed following a protocol based on that from He and other researchers (2002) using

260 DNA extracted from H. pylori 26695 (ATCC 700392D-5) as the positive control (see Table S1

261 for details on the method).

262 Standard curves, which allow for the quantification of each pathogenic bacterium in samples

263 collected from 2013 to 2014 treatment seasons, were created. DNA was extracted from ten-fold

264 dilution series of positive control cultures $\left(10^{8}\right.$ to $\left.10^{\circ} \mathrm{CFU} / \mathrm{mL}\right)$ in tryptic soy broth (TSB, BD-

265 Difco). Prior to the DNA extraction, 10-mL volumes of each dilution of the positive control

266 samples were pelleted at $3200 \mathrm{x}$ g for 10 minutes followed by DNA extraction using the

267 PowerSoil MoBio kit (MoBio, Carlsbad, CA, USA), with a final elution volume of $100 \mu \mathrm{L}$. The

268 TaqMan qPCR assays were performed as described above. The obtained standard curves for all

269 pathogenic bacteria had qPCR efficiencies ranging from $82 \%$ to $108 \%$, with $\mathrm{R}^{2}$ values ranging

270 from 0.986 to 0.998 . Two technical replicates were run for all standards, samples, negative

271 controls (DNA extracted from $10 \mathrm{~mL}$ of sterile TSB), non-template controls and the difference of 
272 the threshold cycle (Ct) value between the replicates was less than 0.5 . The limit of detection

273 (LOD) of the qPCR assay was determined to be $1 \mathrm{CFU} / \mathrm{mL}$ for Salmonella spp., $1 \mathrm{CFU} / \mathrm{mL}$ for $C$.

274 jejuni, C. lari and C. coli, respectively, $10 \mathrm{CFU} / \mathrm{mL}$ for L. monocytogenes, and $10^{3} \mathrm{CFU} / \mathrm{mL}$ for

275 pathogenic E. coli serotypes. Quantity of approximate cell numbers for each pathogenic

276 bacterium was reported as Log CFU/100 mL. The absence of PCR inhibitors in the DNA extracts

277 was confirmed in experiments with each positive bacterial strain spiked into wastewater samples

278 (data not shown).

280 Confirmation of the presence of pathogenic Campylobacter spp. by triplex polymerase chain reaction (PCR)

282 The TaqMan assay (Lund et al. 2004) was designed to detect six species of Campylobacter. 283 Samples that tested positive for Campylobacter spp. in the TaqMan qPCR assay were further 284 analyzed for the presence of C. jejuni, C. lari, or C. coli in a triplex PCR method (Khan and 285 Edge 2007). PCR reactions ( $25 \mu \mathrm{L}$ ) contained $12.5 \mu \mathrm{L}$ of master mix (Taq $2 \mathrm{X}$ Master Mix, New 286 England Biolabs), $0.5 \mu \mathrm{L}$ of each $10 \mu \mathrm{M}$ forward and reverse primers, $1 \mu \mathrm{L}$ of sample DNA and $2878.5 \mu \mathrm{L}$ of Dnase-free water. The triplex PCR reactions contained the following forward and 288 reverse primers: J-UP/J-DN for detection of $C$. jejuni (349 bp), L-UP/L-DN for detection of $C$. 289 lari (279 bp), and C-UP/C-DN for detection of C. coli (72 bp) and was performed in a T290 Gradient thermocycler (Biometra). The PCR condition had initial denaturation at $95{ }^{\circ} \mathrm{C}$ for 3 291 minutes, followed by 35 cycles of denaturation at $95{ }^{\circ} \mathrm{C}$ for 30 seconds, annealing at $45.6{ }^{\circ} \mathrm{C}$ for 29230 seconds, extension at $68^{\circ} \mathrm{C}$ for 45 seconds, and had a final extension at $68{ }^{\circ} \mathrm{C}$ for 5 minutes. 293 Each PCR run contained positive controls (DNA from C. jejuni, C. lari, and C. coli), samples 294 and non-template controls. PCR products were detected by $2 \%$ agarose gel electrophoresis. For 
295 the TaqMan assay to detect Campylobacter spp., the detection limit for the enriched sample was

$2961 \mathrm{CFU} / 10 \mathrm{~mL}$ (enriched to at least $50 \mathrm{CFU} / \mathrm{mL}$ of Bolton enrichment broth), while for the triplex

297 PCR, the detection limit was $1 \mathrm{CFU} / \mathrm{mL}$ for C. jejuni, C. coli, C. lari, respectively.

299 Statistical analysis

300 The normality of the data presented in this paper was checked by D'Agostino-Pearson

301 omnibus normality test in Prism 7 (version 7.0b, Graph Pad Software, Inc., La Jolla, CA, USA).

302 The test result showed that the data did not follow a normal distribution. Differences between

303 two groups were therefore tested with the non-parametric t-test (Mann-Whitney test) while

304 differences among three groups were tested using the non-parametric one-way ANOVA test

305 (Kruskal-Wallis test). The Spearman rank correlation test was used to assess the correlation

306 between the concentrations of E. coli and other related wastewater parameters. All the tests

307 mentioned above were performed in Prism 7 (version 7.0b, Graph Pad Software, Inc., La Jolla,

308 CA, USA). Differences among Spearman rank correlation coefficients $\left(r_{s}\right)$ were considered

309 significant if $\mathrm{p}<0.05$.

311 RESULTS AND DISCUSSIONS

313 Pond environment and wastewater quality in the one-cell and two-cell arctic WSPs

314 The pond surface temperature, $\mathrm{pH}$ and DO profiles obtained from the Pond Inlet and Clyde

315 River WSPs during the 2012, 2013 and 2014 treatment seasons are presented in Figures 1 and 2, 316 respectively. 
318 the treatment season (2012: 13.1 to $16.9{ }^{\circ} \mathrm{C}$; $2014: 11.1$ to $17.8^{\circ} \mathrm{C}$ ) followed by a decrease to

319 4.3-5.4 ${ }^{\circ} \mathrm{C}$ at the end of the season in 2012 and 2014 (Figure 1a). A similar trend was seen in

320 2013, except the temperature fluctuated during the last part of the season from $15.9^{\circ} \mathrm{C}$ to $8.8^{\circ} \mathrm{C}$,

321 followed by an increase to $14.6{ }^{\circ} \mathrm{C}$ and then a gradual decrease to $2.0^{\circ} \mathrm{C}$ at the end. In 2012 ,

322 temporal spikes in $\mathrm{pH}$-values were observed in the WSP where $\mathrm{pH}$ rose from 7.5 to 8.1 mid-

323 season (Figure 1b), suggesting algal growth. The $\mathrm{pH}$ stayed at about 7.7 for the remainder of the

324 treatment season. In 2013, however, the $\mathrm{pH}$ gradually increased from 7.2 to 7.6 over the

325 treatment season with no apparent spikes. In 2014, the pH gradually increased from 7.6 to 8.0

326 mid-season and followed by a slow decrease to 7.7. Interestingly, the constant low levels of DO

327 close to or below $0.2 \mathrm{mg} / \mathrm{L}$ through the entire summer season in 2012 (Figure 1c) contradicted

328 the presence of algal growth that was indicated by $\mathrm{pH}$ measurements that year.

329 In Clyde River, the pond surface temperatures similarly peaked mid-season (Figure 2a).

330 For example, during the sampling trip in 2013, the highest temperature of $13.7^{\circ} \mathrm{C}$ was observed

331 in mid-July compared to $6.2^{\circ} \mathrm{C}$ in the late June and $2.9^{\circ} \mathrm{C}$ in September. Figure $2 \mathrm{~b}$ shows pond

332 pH-values in 2014 exhibited a small peak going from 7.4 to 7.8 around mid-season after which

333 the pH stabilized at 7.4-7.5 for the remainder of the season. Similarly to observations in Pond

334 Inlet WSPs, pH-values in Clyde River gradually increased from 7.3 to 7.6 during the 2013

335 treatment season. DO levels consistently remained below the detection limit $(0.2 \mathrm{mg} / \mathrm{L})$ in both

3362013 and 2014 (data not shown), suggesting that the secondary pond remained anaerobic during

337 the summer treatment seasons for two consecutive years.

338 An assessment of efficiency of the wastewater treatment offered by the one-cell Pond

339 Inlet and two-cell Clyde River WSPs revealed that the anaerobic ponds effectively removed total 
340 suspended solids (TSS) to approach the Canadian municipal wastewater standards ( $25 \mathrm{mg} / \mathrm{L}$ ),

341 however, removal of carbonaceous biochemical oxygen demand ( $\left.\mathrm{CBOD}_{5}\right)$ was limited due to

342 low temperatures and anaerobic environments within the WSPs (Ragush et al. 2015). Taken

343 together, it appeared that the WSPs only delivered limited primary treatment when it comes to

344 the removal of nutrients. While WSPs in both communities were intended to operate as

345 facultative ponds, this was not consistently the case, likely due to the cool arctic summers. 

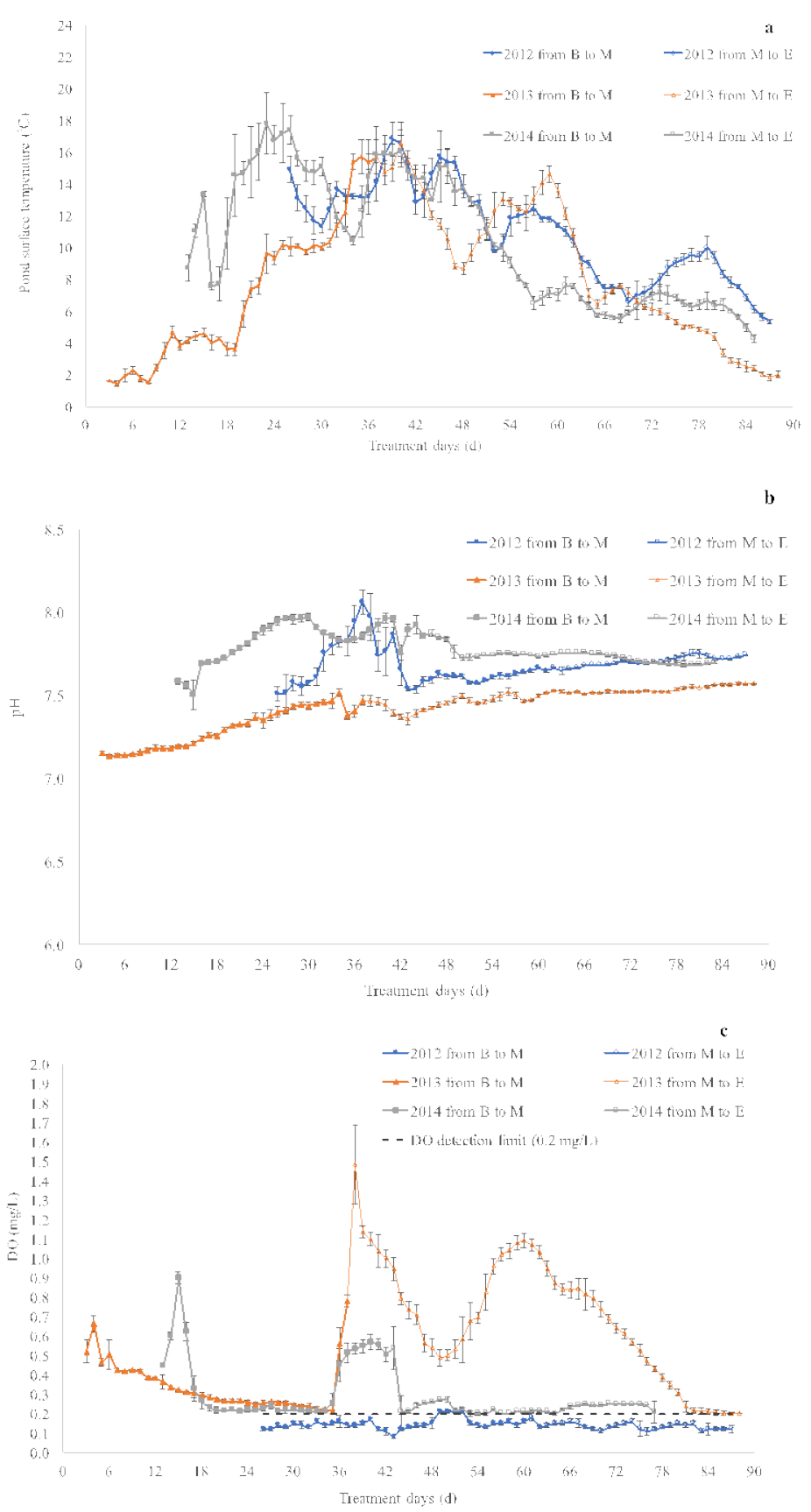

350 Figure 1. Environment in the Pond Inlet waste stabilization pond during the treatment seasons of 351 2012, 2013 and 2014 shown by a) the surface pond temperature, b) wastewater pH and c) DO 352 concentrations. Each data point represents daily averages of hourly measurements ( $\mathrm{n}=24$, mean \pm 353 standard deviation). Closed symbols indicate values obtained between the beginning (B) and 354 middle (M) of the treatment season while the open symbols indicate values obtained between $\mathrm{M}$ 355 and the end $(\mathrm{E})$ of the treatment season. 


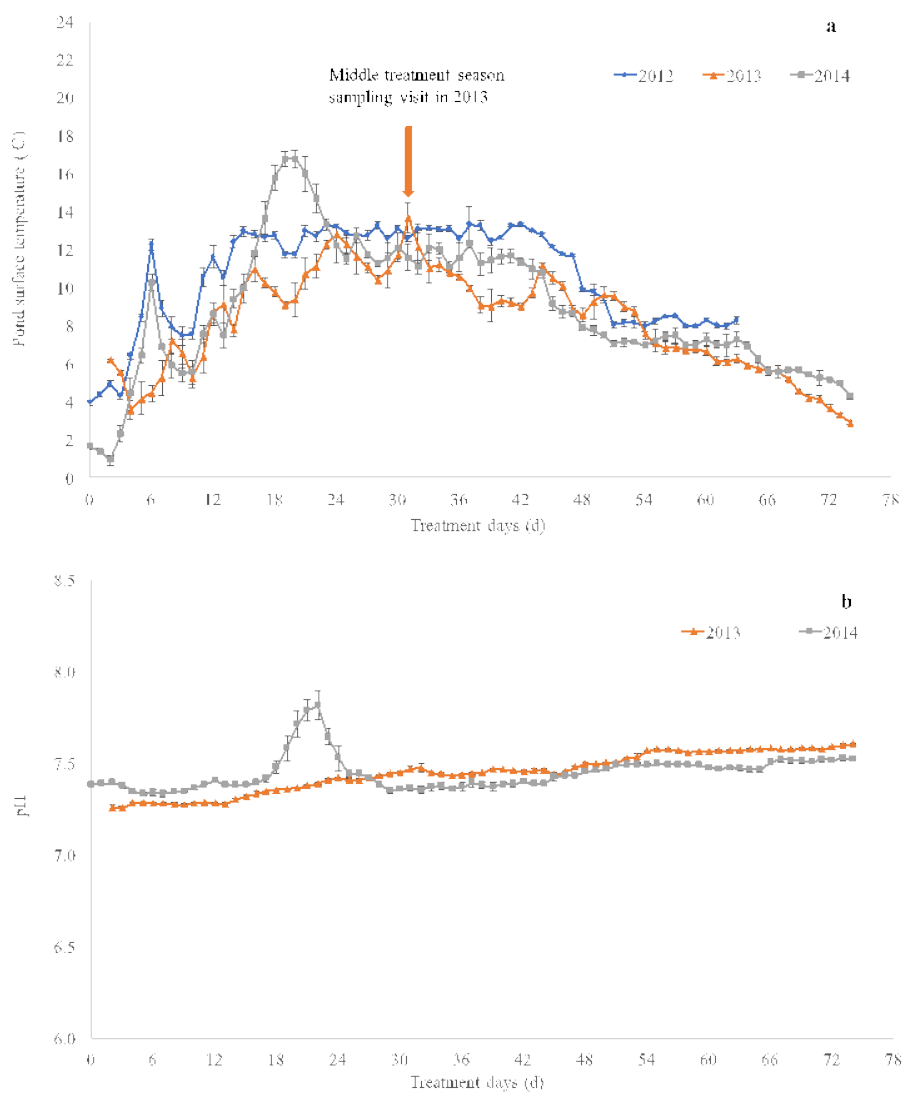

358 Figure 2. Environment in the secondary waste stabilization pond in Clyde River during the

359 treatment seasons of 2013 and 2014 shown by a) the surface pond temperature (also 2012) and b)

360 wastewater $\mathrm{pH}$. Each data point represents daily averages of hourly measurements (n=24, mean

$361 \pm$ standard deviation). The DO levels consistently remained below the detection limit $(0.2 \mathrm{mg} / \mathrm{L})$

362 and the data is therefore not shown.

363

364 Disinfection treatment in arctic WSPs

365 Removal of $E$. coli

366 In Pond Inlet, E. coli levels were on average reduced by 1.5 Log MPN/100 mL as raw

367 wastewater levels of 7.2-7.5 Log MPN/100 mL were reduced to final E. coli levels averaging 5.8 
Log MPN/100 mL in the effluent (Figure 3), which was within the permitted 4-6 Log MPN/100

$369 \mathrm{~mL}$ in the current territorial effluent standards (Nunavut Water Board 2014). In the early to mid-

370 season of 2012 and 2013, CBOD 5 and TSS levels exhibited a strong relationship with the

371 reduction of E. coli concentrations to the lowest levels of 5.3 Log MPN/100 mL, as indicated by

372 the Spearman Rank Correlation coefficients $\left(\mathrm{r}_{\mathrm{s}}\right)$ of 0.64 and $0.75(\mathrm{p}<0.05)$, respectively.

373 However, in the later part of the treatment season, i.e., from late July/early August to

374 early/middle September, E. coli levels rose significantly ( $\mathrm{p}<0.05)$ from 5.3 to 5.9 Log MPN/100

$375 \mathrm{~mL}$. Taken together, it appeared that the disinfection (i.e., E. coli removal) and removal of

376 suspended solids (TSS) and nutrients (CBOD $)$ (Ragush et al. 2015) were optimal in the middle

377 of the treatment season.

378 In Clyde River, just prior to decant in September, E. coli similarly reached levels in the

379 secondary pond that met the current territorial effluent standard (Nunavut Water Board 2014). E.

380 coli concentrations in the raw wastewater in Clyde River ranged from 6.7 to 7.3 Log MPN/100

$381 \mathrm{~mL}$ with no significant differences ( $\mathrm{p}>0.05$ ) among sampling events (Figure 4). Treatment in the

382 primary pond removed an average 1.1 Log MPN/100 mL from the raw wastewater resulting in

383 average E. coli concentrations of 5.9 Log MPN/100 mL in wastewater samples from the primary

384 pond. Within the secondary pond, there was a significant $(\mathrm{p}<0.05)$ reduction of $1.5 \log$

385 MPN/100 mL seen from initial levels in June of 5.5 Log MPN/100 mL to 4.0 Log MPN/100 mL

386 in September, yielding an overall 3 log reduction in the E. coli concentration during the 2012-

3872014 treatment seasons. Reductions in TSS levels correlated $(\mathrm{p}<0.05)$ with the reduction of $E$.

388 coli concentrations in the secondary pond as indicated by the Spearman Rank Correlation

389 coefficient values $\left(r_{s}\right)$ of 0.75 and 0.74 in 2012 and 2014, respectively. In 2013, there was a weak

390 correlation relationship $\left(\mathrm{r}_{\mathrm{s}}=0.45\right)$ between the reduction of TSS and $E$. coli levels in the 
391 secondary pond, which may be due to the direct discharge of raw wastewater into this pond 392 observed during sampling trips in 2013.

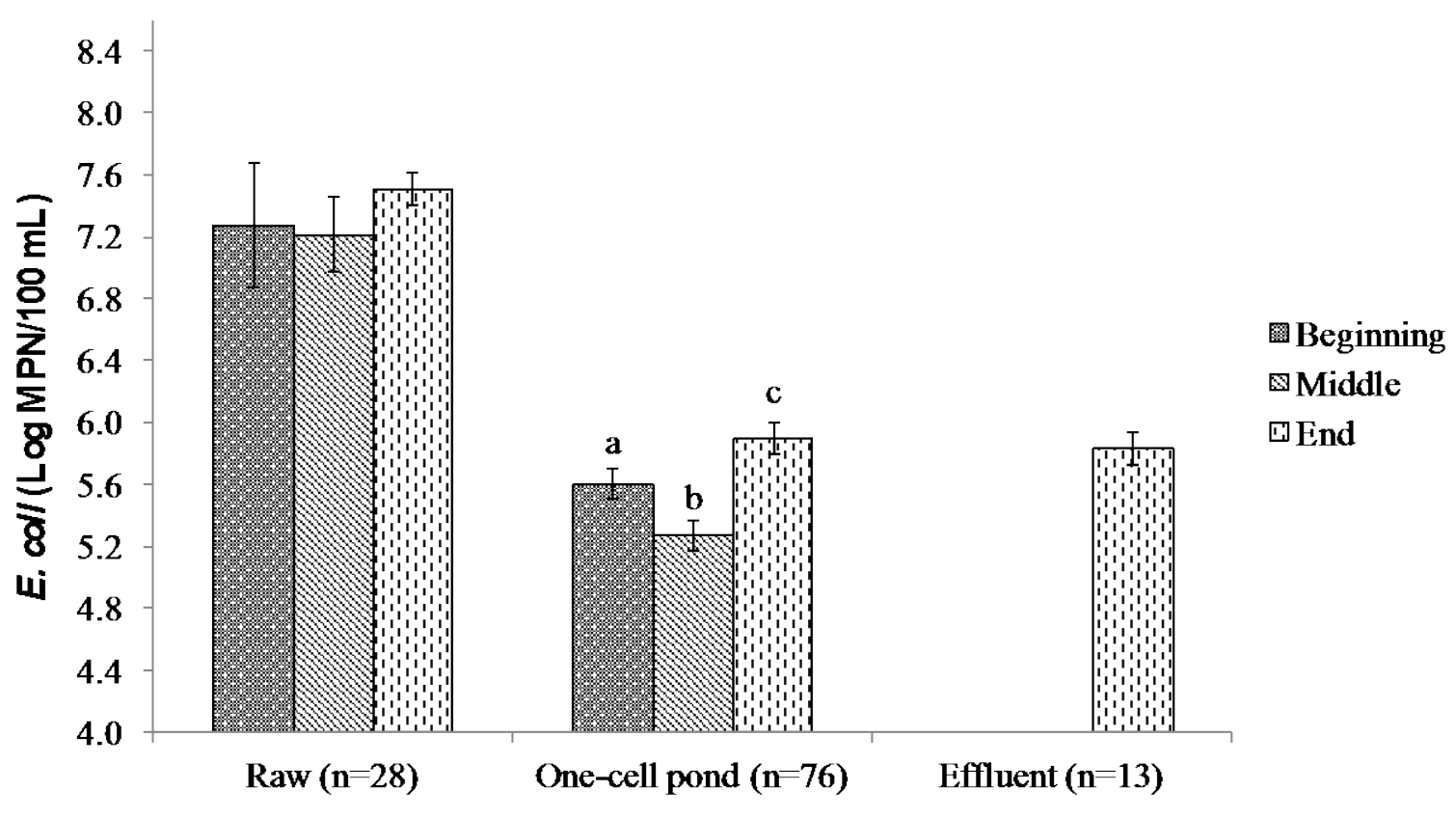

395 Figure 3. The average E. coli levels (Log MPN/100 mL) measured in raw (untreated), one-cell 396 pond and effluent wastewater samples in Pond Inlet in the beginning, middle and end of the 2012 397 to 2014 treatment seasons. Error bars indicate the standard deviation. Different letters within the 398 same sampling site indicate significant differences $(\mathrm{p}<0.05)$ as determined by the Kruskal-Wallis 399 test. 


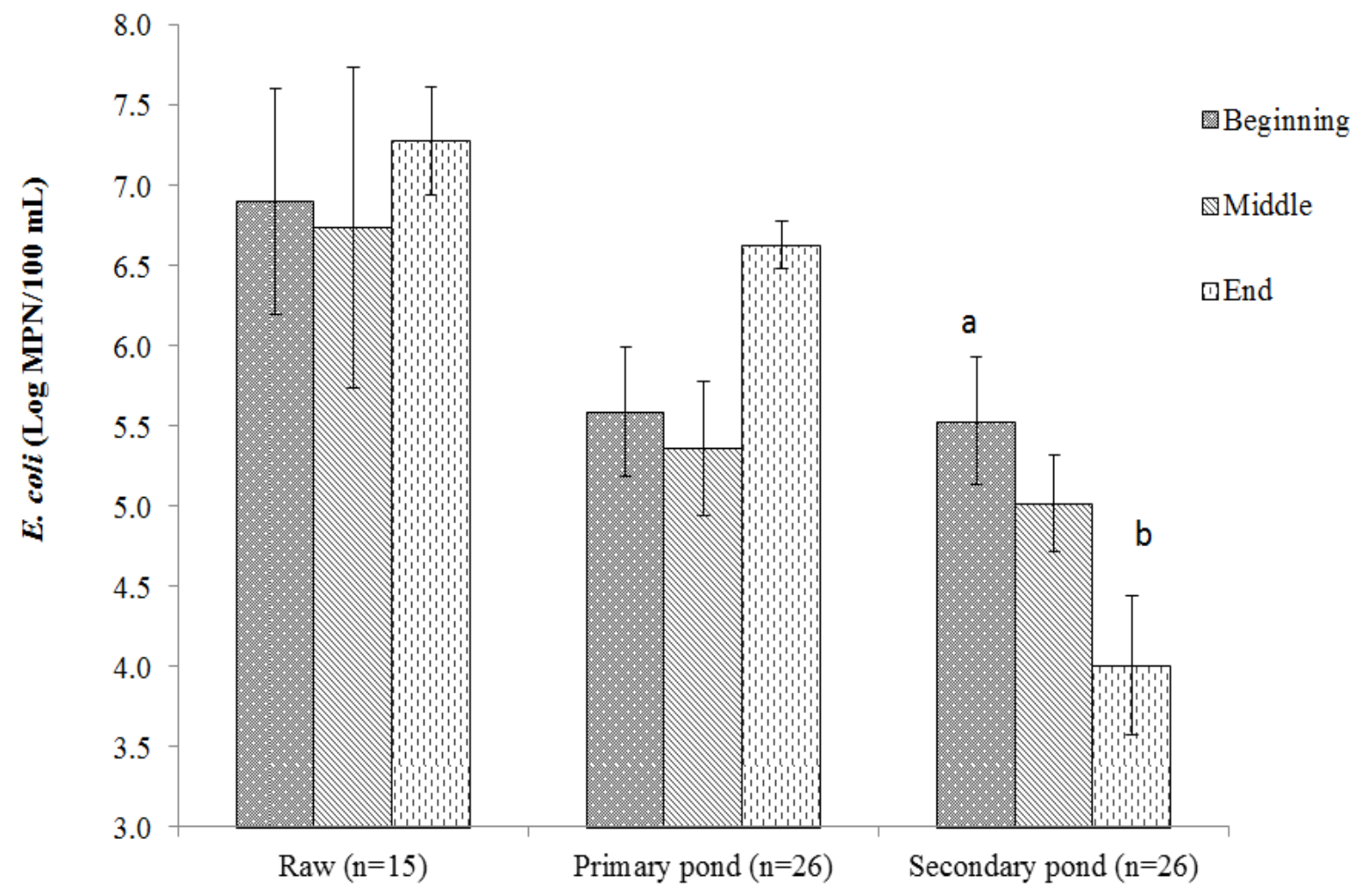

402 Figure 4. The average E. coli levels (Log MPN/100 mL) in raw (untreated) wastewater and 403 samples from the primary and secondary ponds in Clyde River obtained during the 2012 to 2014 404 treatment seasons. Error bars indicate standard deviations. Different letters within the same 405 sampling site indicate significant differences $(\mathrm{p}<0.05)$ as determined by the Mann-Whitney test.

407 Kinetics of $\boldsymbol{E}$. coli removal

408 The kinetics of the removal of E. coli over the different treatment seasons was compared by 409 calculating the first order rate constants in the two WSP systems (Table 1). It should be noted 410 that the first order rate constants were only computed from time periods where the levels of $E$.

411 coli were decreasing. 
414 Table 1. The first order rate constants (k) for E. coli removal in Nunavut WSPs

\begin{tabular}{ccccc}
\hline Location & Year & K (1/day) & $\begin{array}{c}\text { Duration of } \\
\text { summer treatment } \\
\text { (days) }\end{array}$ & $\begin{array}{c}\text { Degree days } \\
\text { above } 5{ }^{\circ} \mathrm{C}\end{array}$ \\
\hline \multirow{3}{*}{ Pond Inlet } & 2012 & $1.4 \times 10^{-4 \mathrm{~A}} \pm 2.5 \times 10^{-6 \mathrm{a}}$ & 33 & 251 \\
& 2013 & $1.7 \times 10^{-3 \mathrm{~B}} \pm 5.1 \times 10^{-5}$ & 34 & 280 \\
& 2014 & $3.3 \times 10^{-3 \mathrm{C}} \pm 1.7 \times 10^{-5}$ & 31 & 308 \\
\hline \multirow{2}{\text{ClydeRiver}}{$\begin{array}{c}\text { (Secondary } \\
\text { pond) }\end{array}$} & 2012 & $5.6 \times 10^{-3 \mathrm{D}} \pm 8.1 \times 10^{-5 \mathrm{~b}}$ & 64 & 324 \\
\hline
\end{tabular}

a: average of calculated $\mathrm{k}$ values in Pond Inlet between two sampling events from 14 biological replicates with two technical duplicates (mean \pm

b: average of calculated k values in Clyde River between two sampling event from eight biological replicates with two technical duplicates (mean

\pm standard deviation)

422 removal from the beginning to the middle of the treatment season in each of the study years

423 (Table 1) with the highest first order rate constant occurring in 2014, followed by 2013 and then

424 2012. Since previous studies found that temperature plays an important role in inactivation of $E$.

425 coli in WSPs (Curtis et al. 1992, Davies-Colley et al. 2000, Klock et al. 1971, Marais et al. 1974),

426 the degree days above $5{ }^{\circ} \mathrm{C}$ were calculated for these time periods. The trend of degree days

427 above $5{ }^{\circ} \mathrm{C}$ indicated that the pond in 2014 (308 degree days above $5^{\circ} \mathrm{C}$ ) experienced a

428 relatively warmer environment than in 2013 (280 degree days above $5{ }^{\circ} \mathrm{C}$ ) and $2012(251$ degree

429 days above $5^{\circ} \mathrm{C}$ ) and offers a possible explanation for observed differences in the first order rate

430 constants for E. coli removal over the three study years. This finding agreed with past WSP

431 studies in non-arctic regions, which also showed the importance of temperature in $E$. coli die-off

432 kinetics (Marais et al. 1974, Polprasert et al. 1983, Klock et al. 1971). The seasonal and annual 
433 variations in $\mathrm{pH}$ and DO (Figures 1b and 1c) also appeared to relate to disinfectant treatment

434 efficiencies, for example, in 2014 a drop in E. coli levels coincided with increased pH (7.6 to 8.0)

435 and DO (0.2 to $0.6 \mathrm{mg} / \mathrm{L})$ levels. Previous studies have shown that $\mathrm{pH}$ values exceeding 9 , and

436 increased DO levels, effectively removed fecal coliforms including E. coli in WSPs (Curtis et al.

437 1992, Parhad and Rao 1974, Pearson et al. 1987).

438 In Clyde River, the first order rate constant for E. coli removal was highest in 2012 and

439 lowest in 2013, which again appeared linked to a comparatively warmer environment in 2012

440 compared to the other years (Table 1). For this community, however, $\mathrm{pH}$ levels were relatively

441 stable and DO levels were constantly below the detection limits, indicating that algae were

442 unlikely to grow (Figure 2). Overall, the observed differences in E. coli removal kinetics

443 indicated annual variations in disinfection treatment performance within the same passive

444 treatment system and geographical location, which may in part be due to local climatic

445 fluctuations.

446

447 Removal of human bacterial pathogens in arctic WSPs

448

449

WSP temperature and removal of pathogens

450 The presence of human bacterial pathogens in the Pond Inlet WSP during the 2014 treatment

451 season is depicted in Figure 5. It should be noted that a similar trend was seen in 2013. The non-

452 enteric environmental pathogen L. monocytogenes was consistently present in $100 \%$ of the

453 samples throughout the treatment season. Results showed that in late June, the enteric pathogens

454 Salmonella spp. and pathogenic E. coli serotypes were present in $88 \%$ and $100 \%$ of the samples,

455 respectively. However, mid-season only 55\% of samples contained Salmonella spp. while 72\% 
456 of samples tested positive for pathogenic E. coli serotypes. On the last visit in conjunction with 457 the annual decant, these numbers rose back up to $79 \%$ and $100 \%$ of the samples testing positive 458 for Salmonella spp. and pathogenic E. coli serotypes, respectively. The other pathogens, C. jejuni, 459 C. lari, C. coli, and H. pylori, were not detected in any samples, indicating that their levels 460 remained below the detection limit.

461 The seasonal temperature variation had no impact on the presence of $L$. monocytogenes, 462 which is a cold-adapted environmental bacterium previously associated with soil, water, and 463 wastewater (Linke et al. 2014). A study of sludge from Swedish sewage treatment plants 464 similarly showed that L. monocytogenes persisted in raw sludge samples (Sahlström et al. 2004). 465 Improved removal of Salmonella spp. and pathogenic E. coli serotypes was observed mid-season 466 coinciding with the highest environmental temperatures. Therefore, similar to the findings for the 467 fecal indicator E. coli removal kinetics, it appeared that the higher WSP temperature measured 468 mid-season in late July/early August (average $13.5^{\circ} \mathrm{C}$ ) improved the removal of Salmonella spp. 469 and pathogenic E. coli serotypes. Taken together, this indicates the importance of temperature 470 (degree days) measurements to gauge the disinfection efficiency (i.e., removal of fecal indicator 471 bacteria) and removal of selected human pathogens in the arctic WSPs. 


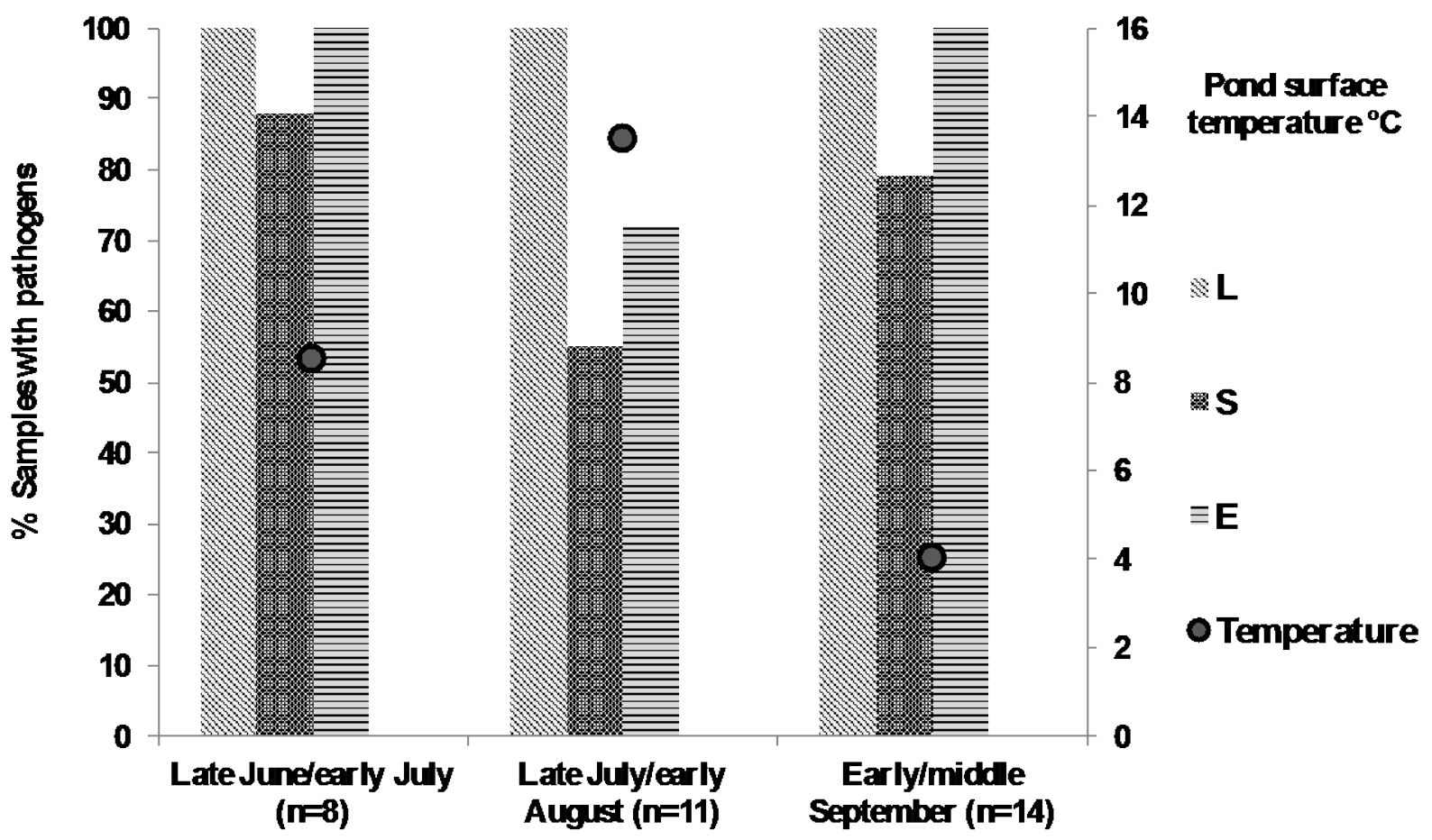

473

474 Figure 5. WSP surface temperature and percentage of WSP samples testing positive for the

475 presence of human pathogens during the 2014 treatment season in Pond Inlet. Legend: $\mathrm{L}-L$.

476 monocytogenes, S - Salmonella spp., and E - pathogenic E. coli serotypes.

478 Removal of human bacterial pathogens along the arctic WSP treatment train

479 The percentage of the samples testing positive for the presence of as well as the direct counts

480 of human pathogens in raw and treated wastewater samples from the WSP systems in Pond Inlet

481 and Clyde River are shown in Tables 2 and 3, respectively.

482

483

484 
Table 2. Percentage of samples testing positive and quantity of human pathogens in raw and treated wastewater samples from the 2013 and 2014 treatment seasons in Pond Inlet.

\begin{tabular}{|c|c|c|c|c|c|c|c|}
\hline \multirow[t]{2}{*}{ Year } & \multirow{2}{*}{$\begin{array}{l}\text { Wastewater } \\
\text { samples } \\
\text { (no. } \\
\text { enriched } \\
\text { samples) }\end{array}$} & \multicolumn{3}{|c|}{$\begin{array}{l}\text { Positive samples (\%) } \\
\text { following enrichment }\end{array}$} & \multicolumn{3}{|c|}{$\begin{array}{c}\text { Log CFU/100 mL } \\
\text { following direct detection } \\
\text { (no. positives/total sample no.) }\end{array}$} \\
\hline & & $\mathrm{L}^{\mathrm{a}}$ & $\mathrm{S}^{\mathrm{b}}$ & $\mathrm{E}^{\mathrm{C}}$ & $\mathrm{L}$ & S & $\mathrm{E}$ \\
\hline \multirow{3}{*}{2013} & Raw (8) & 100 & 88 & 88 & $\begin{array}{c}3.8^{\mathrm{Ad}} \pm 0.3 \\
(2 / 4)\end{array}$ & $\begin{array}{c}4.1^{\mathrm{A}} \pm 0.2 \\
(1 / 4)\end{array}$ & $\begin{array}{c}5.5^{\mathrm{A}} \pm 0.5 \\
(1 / 4)\end{array}$ \\
\hline & WSP (23) & 100 & 78 & 87 & $\begin{array}{l}3.4^{\mathrm{A}} \pm 0.2 \\
(7 / 7)\end{array}$ & $\begin{array}{l}3.6^{\mathrm{B}} \pm 0.1 \\
(3 / 7)\end{array}$ & $\begin{array}{c}4.8^{\mathrm{B}}+0.2 \\
(3 / 7)\end{array}$ \\
\hline & Effluent (6) & 100 & 83 & 83 & $\begin{array}{l}3.5^{\mathrm{A}} \pm 0.3 \\
(4 / 4)\end{array}$ & $\begin{array}{l}3.4^{\mathrm{B}} \pm 0.3 \\
(2 / 4)\end{array}$ & $\begin{array}{c}4.6^{\mathrm{B}} \pm 0.3 \\
(2 / 4)\end{array}$ \\
\hline \multirow{3}{*}{2014} & Raw (9) & 100 & 89 & 100 & $\begin{array}{l}4.2^{\mathrm{A}}+0.4 \\
(4 / 4)\end{array}$ & $\begin{array}{l}4.5^{\mathrm{A}} \pm 0.3 \\
(2 / 4)\end{array}$ & $\begin{array}{c}5.5^{\mathrm{A}} \pm 0.4 \\
(3 / 4)\end{array}$ \\
\hline & WSP (27) & 100 & 74 & 89 & $\begin{array}{l}3.5^{\mathrm{A}}+0.5 \\
(7 / 7)\end{array}$ & $3.7^{\mathrm{B}}+0.1$ & $\begin{array}{c}4.5^{\mathrm{B}}+0.3 \\
(5 / 7)\end{array}$ \\
\hline & Effluent (4) & 100 & 75 & 75 & $\begin{array}{c}3.6^{\mathrm{A}}+0.4 \\
(4 / 4)\end{array}$ & $\begin{array}{c}3.6^{\mathrm{B}}+0.2 \\
(3 / 4)\end{array}$ & $\begin{array}{c}4.5^{\mathrm{B}}+0.2 \\
(3 / 4)\end{array}$ \\
\hline
\end{tabular}

${ }^{a} \mathrm{~L}:$ L. monocytogenes

b: Salmonella spp.

${ }^{\mathrm{c}} \mathrm{E}$ : Pathogenic E. coli serotypes

${ }^{\mathrm{d}}$ Different capital letters in the same column indicate that there were significant differences $(\mathrm{p}<0.05)$ detected by the Kruskal-Wallis test (mean \pm standard deviation).

In Pond Inlet, all three pathogens were detected at levels ranging from 1,000-10,000 copies/100 mL in the September decant (effluent) samples (Table 2). L. monocytogenes was

495 consistently present in all raw (untreated), WSP (treated), and effluent samples at unchanged

496 levels, suggesting that this bacterium was not removed in the Pond Inlet WSP. Salmonella spp.

497 were present in 88-89\% of raw and 74-78\% of treated samples in 2013 and 2014, indicating a

498 consistent presence. The concentration of Salmonella spp. fell significantly $(\mathrm{p}<0.05)$ by $0.5-0.8$

499 Log CFU/100 mL from raw to treated/effluent wastewater samples, indicating some removal in

500 the WSP. Depending on the year, 88 to $100 \%$ of raw wastewater samples tested positive for

501 pathogenic E. coli serotypes. While the level of positive samples stayed high in the treated 
samples, the quantitative analysis revealed that the pathogenic E. coli population was reduced by 0.7-1.0 Log CFU/100 mL. The three major Campylobacter pathogens (C. jejuni, C. lari, and C. coli) were not detected in neither the enriched samples nor by direct enumeration, indicating a

505 low prevalence in the Pond Inlet wastewater treatment system.

506

Table 3. Percentage of samples testing positive and quantity of human pathogens in raw and

Wastewater Positive samples

Year (September)
(\%) following enrichment samples (no. samples)
Log CFU/100 mL following direct detection (no. positive samples)

\begin{tabular}{|c|c|c|c|c|c|c|c|}
\hline & & $\mathrm{L}^{\mathrm{a}}$ & $\mathrm{S}^{\mathrm{b}}$ & $\mathrm{E}^{\mathrm{C}}$ & $\mathrm{L}$ & $S$ & $\mathrm{E}$ \\
\hline \multirow{3}{*}{2013} & Raw (4) & 100 & 100 & 100 & $4.6^{\mathrm{Ad}} \pm 0.3$ & $5.1^{\mathrm{A}}+0.2$ & $5.2^{\mathrm{A}} \pm 0.5$ \\
\hline & Primary (4) & 100 & 100 & 100 & $4.4^{\mathrm{A}}+0.2$ & $4.9^{\mathrm{A}}+0.1$ & $4.9^{\mathrm{A}}+0.2$ \\
\hline & $\begin{array}{c}\text { Secondary } \\
(4)\end{array}$ & 100 & 100 & 100 & $\begin{array}{c}4.5^{\mathrm{A}}+0.3 \\
(4)\end{array}$ & $4.6^{\mathrm{A}}+0.3$ & $4.7^{\mathrm{A}}+0.3$ \\
\hline \multirow{3}{*}{2014} & Raw (4) & 100 & 75 & 100 & $\begin{array}{c}4.5^{\mathrm{A}}+0.3 \\
(4)\end{array}$ & $4.8^{\mathrm{A}}+0.3$ & $\begin{array}{c}4.9^{\mathrm{A}}+0.4 \\
\text { (3) }\end{array}$ \\
\hline & Primary (4) & 100 & 100 & 100 & $4.2^{\mathrm{A}}+0.2$ & $4.4^{\mathrm{B}}+0.1$ & $4.3^{\mathrm{B}}+0.3$ \\
\hline & $\begin{array}{c}\text { Secondary } \\
\text { (4) }\end{array}$ & 75 & 50 & 75 & $3.5^{\mathrm{B}}+0.3$ & $3.6^{\mathrm{C}}+0.2$ & $3.4^{\mathrm{C}}+0.2$ \\
\hline
\end{tabular}

bs: Salmonella spp.

${ }^{\mathrm{c}} \mathrm{E}$ : Pathogenic E. coli serotypes

${ }^{\mathrm{d}}$ Different capital letters in the same column indicate that there were significant differences $(\mathrm{p}<0.05)$ detected by the Kruskal-Wallis test (mean \pm standard deviation).

In Clyde River in 2013 all three pathogens were detected in all raw sewage and grab

516 samples from both the primary and secondary pond during the September sampling visit, shortly

517 before the annual decant event (Table 3). In 2013, the levels of all three pathogens remained

518 unchanged $(\mathrm{p}>0.05)$ along the treatment system. To improve the performance of the two-cell 
519 WSP system in Clyde River, it was proposed based on the treatment suggestions by Dawson and

520 Grainge (1969) and Heinke et al. (1991), that the community use the system in a manner where

521 the smaller primary pond is utilized as a primary treatment cell followed by the transfer of pre-

522 settled wastewater from the primary pond to the secondary, larger pond. Clyde River followed

523 this suggestion in 2012, but returned to dumping raw wastewater into the secondary pond from

524 mid-August to early September in 2013 due to the lack of holding capacity in the primary pond.

525 It may be that this caused the poor disinfection and removal of pathogen performance in 2013;

526 however, 2013 was also a year characterized by lower temperatures (Table 1).

527 In 2014, Clyde River was able to operate the system according to the recommendations,

528 which led to a reduction of pathogens in treated wastewater samples from the secondary pond. In

529 absolute numbers, this resulted in reductions of one $\log$ for $L$. monocytogenes, $0.8 \log$ for

530 Salmonella spp., and 0.9 log for pathogenic E. coli serotypes. In line with past observations of a

531 relationship between TSS and pathogen removal (Bitton 2011), the current observation of

532 pathogen removal coincided with a significant reduction of TSS observed in the secondary pond

533 (Ragush et al. 2015).

$534 \quad$ Campylobacter spp. and H. pylori was not detected in any of samples during sampling

535 events in Pond Inlet and Clyde River. While their presence might have been expected in the raw

536 sewage (Goldfarb et al. 2013), one possible reason for the absence of Campylobacter spp. in the

537 WSP samples is their thermophilic nature, making them vulnerable to the cold arctic climate. It

538 has previously been reported that viable and culturable Campylobacter spp. numbers quickly

539 decreased following the discharged of untreated sewage into coastal waters (Jones et al. 1999a).

540 The same study also found that Campylobacter spp. suspended in the effluent became

541 unculturable after only 15 minutes of exposure to direct sunlight. During the study period, a high 
542 level of incident solar radiation was measured during sunny days with clear sky in Pond Inlet

543 (Ragush et al. 2015), which may have aided in the inactivation of Campylobacter spp.

544 In terms of the detection of bacterial pathogens in the adjacent environment during the

545 September decant in Pond Inlet, all four outfall samples contained L. monocytogenes (average

5463.2 Log CFU/100 mL), Salmonella spp. (average 2.2 Log CFU/100 mL) and pathogenic E. coli

547 serotypes (average 4.1 Log CFU/100 mL). Prior to the decant event, all ocean samples tested

548 negative for the pathogens. However, during the decant event, two pathogens (L. monocytogenes

549 and Salmonella spp.) were detected in all three ocean samples at average levels of 2.1 and 1.5

550 Log CFU/100 mL, respectively.

551 The presence of pathogens in the effluent may pose a risk to human health through various

552 exposure pathways but this will obviously depend on the number and survival of the pathogens

553 being released into the arctic environment and the human and wild-life interactions with

554 impacted areas (Harper et al. 2011, Daley et al. 2017). The predicted infectious dose for

555 pathogenic enterohemorrhagic E. coli serotypes such as O157:H7 is only 10 to 100 bacteria

556 (Theron and Cloete 2002), while for L. monocytogenes it is $10^{7}-10^{8} \mathrm{CFU}$ in healthy hosts and

$55710^{5}-10^{7} \mathrm{CFU}$ in susceptible individuals (Farber et al. 1996). The infectious dose is $10^{3}-10^{5} \mathrm{CFU}$

558 for non-typhoidal Salmonella spp. (Bronze and Greenfield 2005, Ryan and Ray 2004). The

559 prevalence of acute gastrointestinal illness (AGI) is reported to be higher in Arctic Canada

560 compared to other parts of the country (Harper et al. 2015), however, the cause of this remains

561 uncertain. Goldfarb et al. (2013) investigated the presence of a range of bacterial, parasitic, and

562 viral agents in patients with diarrhea in Nunavut and commented on their inability to track the

563 source of the observed infectious agents. The source of food and waterborne infectious agents

564 can be local, as in present in locally harvested foods (mammals and fish) or drinking water, or 
565 imported. The latter appeared to have been the case in the E. coli O157:H7 outbreak in Arviat

566 (NU) where imported frozen hamburger patties was a likely source (Orr et al. 1994). Few studies

567 exist on the prevalence of pathogens in local food sources. Gauthier et al. (2010) reported that

568129 samples of arctic mammals, fowl, fish and community freezers in Nunavik tested negative

569 for the presence of E. coli O157:H7 and Salmonella spp. While it must be assumed that agents of

570 AGI end up in the municipal wastewater treatment systems, little is known about the potential

571 attributions to human disease and wild-life carriage of pathogens being released with (un)treated

572 wastewater in the arctic. A survey of the release of pathogens into the Antarctic Ocean due to

573 wastewater disposal from Antarctic research stations found that microorganisms released from

574 wastewater remained viable for prolonged periods and thus available for transmission to the local

575 fauna (Gröndahl et al. 2009). Earlier studies had reported the presence of human pathogens

576 (Salmonella Enteritidis, Salmonella Typhimurium, Campylobacter jejuni, and Pasteurella

577 multocida) in antarctic seal and bird populations leading the researchers to speculate that the

578 presence of these pathogens could presumptively be attributed to human activity (Broman et al.

579 2000, Palmgren et al. 2000). Clearly, future studies are needed to uncover whether the release of

580 human pathogens from the discharge of untreated and treated wastewater from arctic

581 communities constitute a human health hazard.

583 CONCLUSIONS

584 The study investigated the disinfection and removal of human pathogens in arctic WSPs

585 treating municipal wastewater in Pond Inlet and Clyde River, Nunavut, Canada. The results

586 revealed that WSPs in both communities reduced the content of $E$. coli to levels that are in

587 compliance with the Nunavut Water Board (2014) regulatory limits. The seasonal pond 
temperatures appeared to influence the treatment efficiency. The single-cell WSP in Pond Inlet was able to significantly remove Salmonella spp. (0.7-0.9 log) and pathogenic E. coli serotypes

590 ( 1.0 log) but not L. monocytogenes from raw to effluent wastewater. The two-cell Clyde River

591 WSP provided better treatment in regards to disinfection and removal of bacterial pathogens with

592 reductions of 1.0-1.5 log, provided the primary pond was used as the only recipient of raw

593 wastewater which then after a settling period was transferred to the secondary pond for further

594 treatment. The best removal of fecal indicator bacteria and pathogens was achieved mid-season

595 in Pond Inlet, likely due to the warmer water temperatures however, due to the traditional and

596 important harvest of seafood at that time of year, the treated wastewater was not released until

597 just prior to freeze-up in September. In spite of the WSP treatment, it should be noted that the

598 bacterial pathogens were still present in levels of 2-4 Log CFU/100 mL in the treated wastewater

599 being discharged into the receiving environment. In summary, arctic WSPs achieved a modest

600 removal of fecal and pathogenic bacteria from municipal raw sewage with some local, seasonal

601 and year-to-year variations. From a public health perspective, it may be prudent to assess the

602 potential risks that the wastewater effluents pose to human health.

603

604 Acknowledgements.

605 Funding from the Government of Nunavut, Natural Science and Engineering Research Council

606 of Canada (NSERC): Systems Training and Education in Water Assets Research and

607 Development (STEWARD) and the Canadian Water Network is gratefully acknowledged. Also,

608 our team would like to extend our gratitude to the people in Pond Inlet and Clyde River. The

609 gratitude also goes to the Nunavut Research Institute for providing laboratory space in Iqaluit.

610 Finally, our team members (Amy Jackson, Emma Stea, Emmalina Corriveau, Erin Mentink, 
611 Greg Piorkowski, Jessica LeNoble, Joanna Poltarowicz, Justine Lywood, Kiley Daley, Mark

612 Greenwood, Meggie Letman) are sincerely thanked for their help in both laboratory and field

613 work. The funding agencies were not involved in conducting the research or preparing this paper.

614

615

616

617

618

619

620

621

622

623

624

625

626

627

628

629

630

631

632

633

634

635

636

637

638

639

640

641

642

643

644

645

646

647

648

649

650

651

652

\section{References}

APHA (American Public Health Association). (1998) Standard Methods for the Examination of Water and Wastewater. Twentieth Edition. United Book Press, Inc. Baltimore, Maryland, United States.

Bartsch EH, Randall CW (1971) Aerated lagoons: a report on the state of the art. J Water Poll Control Fed 43(4):699-708.

Bitton G (2011). Microbiology of wastewater treatment. Wastewater Stabilization Ponds (4 ed., p. 373). New Jersey: Wiley-Blackwell.

Broman T, Bergström S, On SL, Palmgren H, McCafferty DJ, Sellin M, Olsen B (2000) Isolation and characterization of Campylobacter jejuni subsp. jejuni from Macaroni Penguins (Eudyptes chrysolophus) in the Subantarctic region. Appl Environ Microbiol 66: 449-452. doi: 10.1128/AEM.66.1.449-452.2000

Bronze MS, Greenfield RA (Ed.) (2005) Biodefence Principles and Pathogens Horizon Bioscience.

Cheng CM, Lin W, Van KT, Phan L, Tran NN, Farmer D (2008) Rapid detection of Salmonella in foods using real-time PCR. J Food Protect 71: 2436-2441. doi: 10.4315/0362-028X71.12 .2436

Curtis TP, Mara DD, Silva SA (1992) The effect of sunlight on faecal coliforms in ponds: implications for research and design. Water Sci Technol 26(7-8): 1729-1738.

Daley K, Castleden H, Jamieson R, Furgal C, Ell L (2014) Municipal water quantities and health in Nunavut households: an exploratory case study in Coral Harbour, Nunavut, Canada. Int J Circumpolar Hlth, 73. doi: 10.3402/ijch.v73.23843

Daley K, Jamieson R, Rainham D, Truelstrup Hansen L (2017) Wastewater treatment and public health in Nunavut: a microbial risk assessment framework for the Canadian Arctic. Environ Sci Pollut Res doi: 10.1007/s11356-017-8566-8

Dawson RN, Grainge JW (1969) Proposed design criteria for wastewater lagoons in arctic and sub-arctic regions. J Water Poll Control Fed 41 (2): 237-246. 
Environment Canada (2014) Canadian Climate Normals 1981-2010 Station Data. Clyde River A Station, Nunavut. Retrieved from

655 http://climate.weather.gc.ca/climate_normals/results_1981_2010_e.html?stnID=1743\&lang=e\&d Code $=0 \&$ province $=$ NU \&provBut $=$ Go\&month1 $=0 \&$ month2 $=12$ (Accessed May 3 2014)

Environment Canada (2014) Canadian Climate Normals 1981-2010 Station Data. Pond Inlet A Station, Nunavut. http://climate.weather.gc.ca/climate_normals/results_1981_2010_e.html?stnID=1774\&autofwd= $\underline{1}$ (Accessed May 3 2014)

Environment Canada (2015) Wastewater systems effluent regulations. http://www.ec.gc.ca/euww/. Accessed December 152016

Farber JM, Ross WH, Harwig J (1996) Health risk assessment of Listeria monocytogenes in Canada. Int J Food Microbiol 30: 145-156. doi: 10.1016/0168-1605(96)01107-5

Gauthier M, Simard M, Blais B (2010) Prevalence of Escherichia coli O157:H7 and Salmonella in traditional meats derived from game animals in Nunavik. Rural Remote Hlth 10: 1329.

Goldfarb DM, Dixon B, Moldovan I, Barrowman N, Mattison K, Zentner C, Baikie M, Bidawid S, Chan F, Slinger R (2013). Nanolitre real-time PCR detection of bacterial, parasitic, and viral agents from patients with diarrhoea in Nunavut, Canada. Int J Circumpolar Hlth, 72. doi: 10.3402/ijch.v72j0.19903

Goodman KJ, Jacobson K, van Zanten SV (2008) Helicobacter pylori infection in Canadian and related Arctic Aboriginal populations. Can J Gastroenterol Hepatol 22: 289-295. doi: $10.1155 / 2008 / 258610$

Gröndahl F, Sidenmark J, Thomsen A (2009) Survey of waste water disposal practices at Antarctic research stations. Polar Res 28: 298-306. doi: 10.1111/j.1751-8369.2008.00056.x

Harper SL, Edge VL, Schuster-Wallace CJ, Berke O, McEwen SA (2011) Weather, water quality and infectious gastrointestinal illness in two Inuit communities in Nunatsiavut, Canada: potential implications for climate change. EcoHealth, 8: 93-108. doi: 10.1007/s10393-011-0690-1

Harper SL, Edge VL, Ford J, Thomas MK, Pearl DL, Shirley J, IHACC Research Group, McEwen S (2015) Acute gastrointestinal illness in two Inuit communities: burden of illness in Rigolet and Iqaluit, Canada. Epidemiol Infect 143(14): 3048-3063.

He Q, Wang JP, Osato M, Lachman LB (2002) Real-time quantitative PCR for detection of Helicobacter pylori. J Clin Microbiol 40: 3720-3728. doi: 10.1128/JCM.40.10.3720-3728.2002

Heinke GW, Smith DW, Finch GR (1991) Guidelines for the planning and design of wastewater lagoon systems in cold climates. Can J Civil Eng 18: 556-567. doi: 10.1139/I91-068 
Ibekwe AM, Watt PM, Grieve CM, Sharma VK, Lyons SR (2002) Multiplex fluorogenic realtime PCR for detection and quantification of Escherichia coli O157: H7 in dairy wastewater wetlands. Appl Environ Microbiol 68: 4853-4862. doi: 10.1128/AEM.68.10.4853-4862.2002

Jones K, Anderson S, Obiri-Danso K (1999a) Use of Campylobacter and fecal coliforms to trace sources of pollution on a reservoir. Abstract 29. Society of Applied Microbiology Conference on Aquatic Microbiology, York, July.

705

706

707

708

709

710

711

712

713

714

715

716

717

718

719

720

721

722

723

724

725

726

727

728

729

730

731

732

733

734

735

736

737

738

739

740

741

742
Jones K, Howard S, Wallace JS (1999b) Intermittent shedding of thermophilic campylobacters by sheep at pasture. J Appl Microbiol 86: 531-536. doi: 10.1046/j.1365-2672.1999.00702.x

Khan IUH, Edge TA (2007) Development of a novel triplex PCR assay for the detection and differentiation of thermophilic species of Campylobacter using 16S-23S rDNA internal transcribed spacer (ITS) region. J Appl Microbiol 103: 2561-2569. doi: 10.1111/j.13652672.2007.03511.x

Klock JW (1971) Survival of coliform bacteria in wastewater treatment lagoons. J (Water Poll Control Fed), 43 (10): 2071-2083.

Lefebvre M, Chang HJ, Morse A, van Zanten SV, Goodman KJ, \& CANHelp Working Group (2013) Adherence and barriers to H. pylori treatment in Arctic Canada. Int J Circumpolar Hlth 72. doi: $10.3402 / \mathrm{ijch} . v 72 \mathrm{i} 0.22791$

Linke K, Rückerl I, Brugger K, Karpiskova R, Walland J, Muri-Klinger S, Tichy A, Wagner M, Stessl B (2014) Reservoirs of Listeria species in three environmental ecosystems. Appl Environ Microbiol 80: 5583-5592. doi: 10.1128/AEM.01018-14

Lund M, Nordentoft S, Pedersen K, Madsen M (2004) Detection of Campylobacter spp. in chicken fecal samples by real-time PCR. J Clin Microbiol 42: 5125-5132. doi: 10.1128/JCM.42.11.5125-5132.2004

Lyautey E, Lapen DR, Wilkes G, McCleary K, Pagotto F, Tyler K, Hartmann A, Piveteau P, Rieu A, Robertson WJ, Medeiros DT, Edge TA, Gannon V, Topp E (2007) Distribution and characteristics of Listeria monocytogenes isolates from surface waters of the South Nation River watershed, Ontario, Canada. Appl Environ Microbiol 73: 5401-5410. doi: 10.1128/AEM.0035407

Marais GVR (1974) Fecal bacterial kinetics in stabilization ponds. J Sanit Eng Div 100(1): 119139.

McKeown I, Orr P, Macdonald S, Kabani A, Brown R, Coghlan G, Dawood M, Embil J, Sargent M, Smart G, Bernstein CN (1999) Helicobacter pylori in the Canadian arctic: seroprevalence and detection in community water samples. Am J Gastroenterol 94: 1823-1829. doi: 10.1111/j.15720241.1999.01212.x 
Nunavut Water Board (2014) Public registry FTP. Retrieved from Nunavut Water Board: http://www.nwb-oen.ca/public-registry Accessed November 152016

Orr P, Lorencz B, Brown R, Kielly R, Tan B, Holton D, Clugstone H, Lugtig L, Pim C, Macdonald S, Hammond G, Moffatt M, Spika J, Manuel D, Winther W, Milley D, Lior H, Sinuff N (1994) An outbreak of diarrhea due to verotoxin-producing Escherichia coli in the Canadian Northwest Territories. Scand J Infect Dis 26: 675-684. doi: 10.3109/00365549409008635

Palmgren H, McCafferty D, Aspán A, Broman T, Sellin M, Wollin R, Bergström S, Olsen B (2000) Salmonella in sub-Antarctica: low heterog
Georgian seals and birds. Epi Infect 125(2): 257-262.

Parhad NM, Rao NU (1974) Effect of pH on survival of Escherichia coli. J (Water Poll Control Fed) 46 (5): 980-986.

Pearson HW, Mara DD, Mills SW, Smallman DJ (1987) Physico-chemical parameters influencing faecal bacterial survival in waste stabilization ponds. Water Sci Technol 19(12): 145152.

Polprasert C, Dissanayake MG, Thanh NC (1983) Bacterial die-off kinetics in waste stabilization ponds. J (Water Poll Control Fed), 55: 285-296. doi: 10.2307/25041850

Ragush CM, Schmidt JJ, Krkosek WH, Gagnon GA, Truelstrup-Hansen L, Jamieson RC (2015) Performance of municipal waste stabilization ponds in the Canadian Arctic. Ecol Eng 83: 413421. doi: 10.1016/j.ecoleng.2015.07.008

Ryan KJ, Ray CG (Eds.) (2004.) Sherris Medical Microbiology: An Introduction to Infectious Disease. (Fourth Edition. ed.). New York.: McGraw-Hill.

Rodríguez-Lázaro D, Hernández M, Scortti M, Esteve T, Vázquez-Boland JA, Pla M (2004) Quantitative detection of Listeria monocytogenes and Listeria innocua by real-time PCR: assessment of hly, iap, and lin02483 targets and AmpliFluor technology. Appl Environ Microbiol 70: 1366-1377. doi: 10.1128/AEM.70.3.1366-1377.2004

Rowe PC, Orrbine E, Ogborn M, Wells GA, Winther W, Lior H, Manuel D, McLaine PN (1994) Epidemic Escherichia coli O157:H7 gastroenteritis and hemolytic-uremic syndrome in a Canadian Inuit community: intestinal illness in family members as a risk factor. J Pediatrics 124: 21-26. doi: 10.1016/S0022-3476(94)70249-7

Sahlström L, Aspan A, Bagge E, Danielsson-Tham ML, Albihn A (2004) Bacterial pathogen incidences in sludge from Swedish sewage treatment plants. Water Res 38: 1989-1994. doi: 10.1016/j.watres.2004.01.031

Statistics Canada (2012) Census Profile. 2011 census. Statistics Canada Catalogue no. 98-316XWE. Ottawa. Retrieved from: http://www12.statcan.gc.ca/census-recensement/2011/dppd/prof/index.cfm?Lang=E (Accessed December 30, 2016) 
790 Stea EC, Truelstrup Hansen L, Jamieson RC, Yost CK (2015a) Fecal contamination in the 791 surface waters of a rural- and an urban-source watershed. J Environ Qual 44: 1556-1567. doi: $792 \quad 10.2134 /$ jeq2014.11.0459

794 Stea EC, Purdue LM, Jamieson RC, Yost CK, Truelstrup Hansen L (2015b) Comparison of the 795 prevalence and diversity of Listeria species and Listeria monocytogenes in an urban and a rural 796 agricultural watershed. Appl Environ Microbiol 81: 3812-3822. doi: 10.1128/AEM.00416-15

798 Theron J, Cloete TE (2002) Emerging waterborne infections: contributing factors, agents, and 799 detection tools. Crit Rev Microbiol 28: 1-26. doi: 10.1080/1040-840291046669

800

801 Weatherill S, et al. (2009) Report of the independent investigator into the 2008 Listeriosis 802 outbreak. Health Canada, Ottawa, Canada. Retrieved from: 803 http://www.cpha.ca/uploads/history/achievements/09-lirs-rpt_e.pdf (Accessed December 30, 804 2016)

805

806 
Table S1. Primers and qPCR protocols for detection of bacterial pathogens.

\begin{tabular}{|c|c|c|c|c|}
\hline Assay type & Pathogenic bacteria & $\begin{array}{c}\text { Primers }(\mathrm{F} \text { and } \mathrm{R}) \\
\text { and probes }(\mathrm{P})\end{array}$ & Sequence 5' to 3' & qPCR protocols \\
\hline \multirow[t]{12}{*}{ TaqMan } & \multirow{3}{*}{$\begin{array}{c}\text { Listeria } \\
\text { monocytogenes }\end{array}$} & HlyQF & CATGGCACCACCAGCATCT & \multirow{3}{*}{$\begin{array}{l}95{ }^{\circ} \mathrm{C} \text { for } 10 \mathrm{~min} ; 40 \\
\text { cycles of } 95{ }^{\circ} \mathrm{C} \text { for } 20 \mathrm{sec} \text {, } \\
56{ }^{\circ} \mathrm{C} \text { for } 30 \mathrm{sec}, 72{ }^{\circ} \mathrm{C} \text { for } \\
1 \mathrm{~min}\end{array}$} \\
\hline & & HlyQR & ATCCGCGTGTTTCTTTTCGA & \\
\hline & & HlyQP & FAM-CGCCTGCAAGTCCTAAGACGCCA-TAMRA ${ }^{\mathrm{a}}$ & \\
\hline & \multirow{3}{*}{$\begin{array}{l}\text { Eschericha coli } \\
\text { (pathogenic } \\
\text { EHEC/EPEC, } \\
\text { intimin+) }\end{array}$} & EaeF & GTAAGTTACACTATAAAAGCACCGTCG & \multirow{3}{*}{$\begin{array}{l}95{ }^{\circ} \mathrm{C} \text { for } 6 \text { min; } 40 \text { cycles } \\
\text { of } 95{ }^{\circ} \mathrm{C} \text { for } 20 \mathrm{sec}, 55^{\circ} \mathrm{C} \\
\text { for } 30 \mathrm{sec}, 72{ }^{\circ} \mathrm{C} \text { for } 40 \mathrm{sec}\end{array}$} \\
\hline & & EaeR & TCTGTGTGGATGGTAATAAATTTTTG & \\
\hline & & EaeP & $\begin{array}{l}\text { FAM- } \\
\text { AAATGGACATAGCATCAGCATAATAGGCTTGCT- } \\
\text { BHQ1 }^{\text {b }}\end{array}$ & \\
\hline & \multirow[t]{3}{*}{ Campylobacter spp. } & CampF2 & CACGTGCTACAATGGCATAT & \multirow{3}{*}{$\begin{array}{l}95{ }^{\circ} \mathrm{C} \text { for } 6 \text { min; } 40 \text { cycles } \\
\text { of } 95{ }^{\circ} \mathrm{C} \text { for } 15 \mathrm{sec}, 60{ }^{\circ} \mathrm{C} \\
\text { for } 1 \mathrm{~min}\end{array}$} \\
\hline & & CampR2 & GGCTTCATGCTCTCGAGTT & \\
\hline & & CampP2 & FAM-CAGAGAACAATCCGAACTGGGACA-BHQ1 & \\
\hline & \multirow[t]{3}{*}{ Salmonella enterica } & InvAF & AACGTGTTTCCGTGCGTAAT & \multirow{3}{*}{$\begin{array}{l}95{ }^{\circ} \mathrm{C} \text { for } 6 \text { min; } 40 \text { cycles } \\
\text { of } 95{ }^{\circ} \mathrm{C} \text { for } 15 \mathrm{sec}, 60{ }^{\circ} \mathrm{C} \\
\text { for } 1 \mathrm{~min}\end{array}$} \\
\hline & & InvAR & TCCATCAAATTAGCGGAGGC & \\
\hline & & InvAP & FAM-TGGAAGCGCTCGCATTGTGG-BHQ1 & \\
\hline \multirow[t]{2}{*}{ SybrGreen } & \multirow[t]{2}{*}{ Helicobacter pylori } & HPF & TTATCGGTAAAGACACCAGAAA & \multirow{2}{*}{$\begin{array}{l}95{ }^{\circ} \mathrm{C} \text { for } 10 \mathrm{~min} ; 40 \\
\text { cycles of } 94{ }^{\circ} \mathrm{C} \text { for } 20 \mathrm{sec} \text {, } \\
54{ }^{\circ} \mathrm{C} \text { for } 5 \mathrm{sec}, 72{ }^{\circ} \mathrm{C} \text { for } \\
10 \mathrm{sec}\end{array}$} \\
\hline & & HPR & ATCACAGCGCATGTCTTC & \\
\hline
\end{tabular}




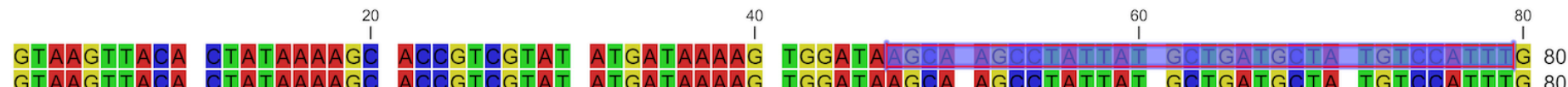

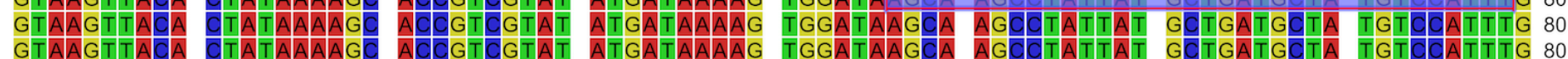 GTAAGTTACA CTATAAAAG ACGGTGGTAT ATGATAAAAG TGGATAAGCA AGCCTATTAT GCTGATGCTA TGTCATTTG 80} GTAAGTTACA CTATAAAAGC ACCGTCGTAT ATGATAAAAG TGGATAAGCA AGCCTATTAT GCTGATGCTA TGTCCATTTG Conservation 2.0 tits Sequence logo

Escherichia coli 0157:H7 Escherichia coli O145:H28

Escherichia coli $\mathrm{O} 55: \mathrm{H} 7$

Escherichia coli O111:H7

Consensus CAAAAATTTA

Conservation $2.0 \%$
$2.06 i t s$
logo
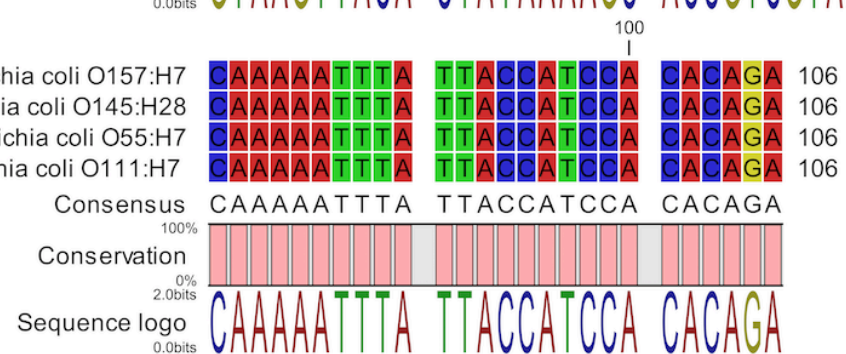

ATCATAAAG TGGTARCCA ACCTITTAT GCTGATCCTA TGTCCATTE

Figure S1. Alignment of the eae gene fragment amplified by the Ibekwe et al. (2002) primer pair from different pathogenic E. coli serotypes showing the binding site for the EaeP probe (CLC Genomics Workbench Version 9). Shown are enterohemorrhagic E. coli (EHEC) strains O157:H7 and O145:H28 and enteropathogenic E. coli (EPEC) strains O55:H7 and O111:H7. A search in the NCBI database (https://www.ncbi.nlm.nih.gov/) revealed that other EHEC and EPEC serotypes were also detected by this primer and probe set including EHEC strains O79:H7, O91:H14, O153:H2, O156:H25, and EPEC strains O55:K59, O126:K71,O86:K61, O44:K74, O26:K60, O128:K67, O127:K63, O126:K71, O125:K70, O119:K69, O111:K59, O111:K58, O82:H11, O40:H19, O170:H49, O2:H40, O119:H25, O76:H7, O136:H21. 